\title{
Bacterial utilization of dissolved humic substances from a freshwater swamp
}

\author{
Nasreen Bano*, Mary Ann Moran, Robert E. Hodson \\ Department of Marine Sciences, University of Georgia, Athens, Georgia 30602-2206, USA
}

\begin{abstract}
Dissolved humic substances from 5 different aquatic habitats in the Okefenokee Swamp, USA, ecosystem were tested for their ability to support growth of natural bacterial communities in batch bioassay experiments. The in situ dissolved organic carbon (DOC) concentration in samples from all sites was high, ranging from 46 to $58 \mathrm{mg} \mathrm{Cl}{ }^{1} ; 63$ to $78 \%$ of the DOC was humic substances. Humic substances were isolated by adsorption onto Amberlite XAD-8 resin and provided to natural bacteria] communities either from the same site or one of the other sites as the only carbon source. Humic substances from all sites supported bacterial growth; generally there were no significant differences among the bacterial communities in the rates or extent of utilization of humic substances. The average specific growth rates of bacteria, determined as changes in biovolume, were 0.026 to $0.044 \mathrm{~h}^{-1}$ for all experiments and were comparable to rates measured in situ. The cumulative bacterial carbon production ranged from 58 to $176 \mu \mathrm{g} \mathrm{C} \mathrm{l}^{-1}$ Based on measures of bacterial carbon production and oxygen consumption, bacterial growth efficiency on humic substances was estimated at $22 \%$, and the percentage of the humic substances pool utilized during the $1 \mathrm{wk}$ bioassay was 0.8 to $1.8 \%$.
\end{abstract}

KEY WORDS: Humic substances B Bacterial growth - Okefenokee Swamp - Freshwater marsh

\section{INTRODUCTION}

Humic substances constitute a large fraction of the dissolved organic matter (DOM) in most natural waters, typically accounting for about $50 \%$ of the DOM (Thurman 1985). Although previously considered nearly inert from a biological standpoint, humic substances are now recognized to play important roles as carbon and energy sources for bacteria and, ultimately, microbial food webs. Initially, evidence for this role came from correlative studies showing that humic-rich waters often supported higher bacterial biomass or production than did waters with low concentrations of humic substances (Hessen 1985, Tranvik \& Höfle 1987. Tranvik 1988). Recently, bacterial bioassay studies have provided more direct evidence that components of the humic substances pool can be assimilated by natural bacterial assemblages and used for growth (Tranvik \& Sieburth 1989, Moran \& Hodson 1990. 1994a, Tranvik 1990).

\footnotetext{
•E-mail: nasreen@uga.cc.uga.edu
}

The potential for humic substances to play an important biological role in aquatic systems will be greatest in those environments with high concentrations of DOC and humic substances. The flux of humic carbon into bacteria has geochemical implications in these systems as well, since the entry of humic substances into the mineralization-intensive microbial loop would compete with other carbon flux pathways, such as flocculation, peat accumulation, or export. It is therefore of interest to determine the magnitude of bacterial utilization of humic substances in freshwater systems with high concentrations of DOM and to learn more about the mechanisms regulating this process.

\section{MATERIALS AND METHODS}

Site descriptions. The Okefenokee Swamp is a large freshwater wetland $\left(1700 \mathrm{~km}^{2}\right)$ located in southeastern Georgia and northeastern Florida, USA. Vegetation in this system is variable, with numerous habitats scattered in mosaic fashion throughoul, including wooded 
swamps, open marshes, and tree islands. Okefenokee Swamp surface water has high concentrations of both DOC and humic substances. The major input of water is from precipitation, with slow sheet movement of surface water from north to south. Thus, depending on the speed of water movement relative to local rates of $\mathrm{DOC}$ production and transformation, local differences may develop in the concentration, chemical composition, or biological availability of humic substances, affected by the dominant vegetation type of each habitat. Further, the utilizability of humic substances may be a function of the local composition of bacterial assemblages, which might be adapted to site-specific differences in the sources or chemical attributes of humic substances.

Dissolved humic substances and natural bacterial communities were oblained from 5 sites in the okefenokee Swamp representing different vegetation types. One site (Cypress Swamp Site or CS) is dominated by woody vegetation, primarily pond cypress Taxodium ascendens; this type of forested swamp accounts for about $29 \%$ of the Okefenokee Swamp area. Two sites are dominated by non-woody vegetation; Chesser Prairie (CP) is an open-water marsh in which white water lily Nuphar advena is the major plant species, while Mizell Prairie (MP) is an emergent grass-sedge marsh dominated by maidencane Panicum hemitomon and sedge Carex spp. Non-woody marshes cover about $23 \%$ of the Okefenokee Swamp area. The last 2 sites represent integrated mixtures of DOC and bacterial communities from many Okefenokee habitats. Sill site (SS) is located at the southern boundary of the Swamp, adjacent to an earthen sill at the source of the Suwannee River; the Suwannee River site (SR) is $22 \mathrm{~km}$ downstream from SS. This river is the route by which humic substances are exported from the Okefenokee Swamp to the Gulf of Mexico.

Sample collection. Water samples were collected on December 12, 1993 from SR site, on March 19, 1994 from CP, CS, and SS sites, and on July 7, 1994 from MP site. Water samples (10 l) were filtered sequentially through ashed Gelman A/E and Whatman GF/F filters, adjusted to $\mathrm{pH} 2$ with $6 \mathrm{~N} \mathrm{HCl}$, and stored on ice for transport to the laboratory. Within $1 \mathrm{~d}$ of collection, the filtered and acidified water samples were brought to room temperature and humic substances (operationally defined as the fraction of DOC that is retained on a hydrophobic macroporus resin at $\mathrm{pH}$ 2) were isolated. The isolation procedure involved pumping the filtered water sample through columns of Amberlite XAD-8 resin, eluting the humic substances with $\mathrm{NaOH}$, and desalting the humic substances concentrate by cation exchange as previously described (Aiken 1985, Moran \& Hodson 1994a). Although the XAD-8 and ion exchange resins were cleaned thoroughly before use (Aiken 1988), any organic matter still bleeding from the resins might have been problematic in subsequent bacterial assays. To control for any effect of resin contamination on bacterial growth, 10 l volumes of distilled/ deionized water were pumped through the columns in a manner identical to that used for Okefenokee samples. The column eluant obtained from these distilled/deionized water samples (designated 'column leachate') was used as controls in the biological availability studies (see below).

Chemical characterization of humic substances. Subsamples of humic concentrate from each site were rotary evaporated, freeze dried, and stored frozen until chemical analysis. Concentrations of 8 characteristic lignin phenols were determined by the method of Hedges \& Ertel (1982) as previously described (Moran et al. $1994 \mathrm{~b}$ ) to provide a relative index of vascular plant influence on the dissolved humic substances. Lignin phenol concentrations were highest in humic substances from the CP site $\left(8.1 \mu \mathrm{g} \mathrm{mg}^{-1}\right.$; Table 1$)$. The total lignin phenol concentration in humic substances of the other sites ranged from 3.2 to $4.0 \mathrm{\mu g} \mathrm{mg}^{-1}$.

Percentages of carbon, hydrogen and nitrogen (CHN) in the freeze-dried humic substances were determined with a Perkin-Elmer 240C CHN analyzer. CHN contents were similar among sites (Table 1) and within the range reported for other aquatic humic substances (Thurman 1985). The $\mathrm{C}: \mathrm{H}$ ratios $(1.02 \pm 0.03$; mean \pm SD) indicate an important aromatic component, and together with the low nitrogen concentrations $(0.85 \pm 0.04 \%)$ suggest sources dominated by lignin-rich vascular plants (Leenheer et al. 1989).

Table 1. Chemical characterization of humic substances at Okefenokee Swamp, USA, sites. DOC: dissolved organic carbon. For humic substances, percentage of DOC given in parentheses

\begin{tabular}{|c|c|c|c|c|c|}
\hline Site & $\begin{array}{c}\mathrm{DOC} \\
\left(\mathrm{mgCl} l^{-1} ; \pm \mathrm{SD}, \mathrm{n}=3\right)\end{array}$ & $\begin{array}{l}\text { Humic substances } \\
\left(\mathrm{mg} \mathrm{Cl} \mathrm{l}^{-1} ; \pm \mathrm{SD}, \mathrm{n}=3\right)\end{array}$ & $\mathrm{C}: \mathrm{N}$ & $\mathrm{C}: \mathrm{H}$ & $\begin{array}{c}\text { Lignin phenols } \\
\left(\mu g \mathrm{mg}^{-1} ; \pm \mathrm{SD}, \mathrm{n}=2\right)\end{array}$ \\
\hline Suwannee River (SR) & $57.7 \pm 0.5$ & $33.4 \pm 4.8 \quad(63)$ & 61.3 & 1.02 & $4.0 \pm 0.28$ \\
\hline Chesser Prairie (CP) & $56.1 \pm 1.1$ & $40.9 \pm 0.11(73)$ & 73.9 & 1.04 & $8.1 \pm 2.0$ \\
\hline Cypress Site (CS) & $46.2 \pm 0.6$ & $35.3 \pm 0.01(76)$ & 66.8 & 0.98 & $4.0 \pm 0.54$ \\
\hline Sill Site (SS) & $53.4 \pm 1.4$ & $41.8 \pm 0.06(78)$ & 67.5 & 1.06 & $3.4 \pm 0.12$ \\
\hline Mizell Prairie (MP) & $53.6 \pm 0.1$ & $34.1 \pm 3.4 \quad\{64\}$ & 70.5 & 1.00 & $3.2 \pm 0.24$ \\
\hline
\end{tabular}


DOC concentration before and after humic substance isolation was measured by direct injection into a high temperature combustion carbon analyzer (Shimadzu TOC-5000) using a 4 point calibration curve with potassium biphthalate as the standard. Seven repeated injections showed within-replicate standard deviations of 0.2 to $1 \%$, and all measurements of DOC concentration were carried out in triplicate. The DOC concentration at all Okefenokee sites was high (46.2 to $57.7 \mathrm{mg} \mathrm{C} \mathrm{C}^{-1}$ ), as was the contribution of humic substances to the DOC pool (>63\% of DOC; Table 1).

Bacterial bioassays. Batch culture experiments were carried out to determine the fraction of the humic substances pool readily utilizable by natural bacterial communities (over time periods of 5 to 7 d). Humic substances from each site were reconstituted in filtersterilized deionized water at concentrations approximately equivalent to natural concentrations at the time of collection. Each solution was amended with inorganic nutrients to final concentrations of $10 \mu \mathrm{MP}$ as $\mathrm{PO}_{4}$ and $60 \mu \mathrm{M} \mathrm{N}$ as $\mathrm{NO}_{3}$ and $\mathrm{NH}_{4}$ (concentrations 5 - to 10-fold higher than typically found) to insure carbonlimited growth, and inoculated with 10 to $20 \mathrm{ml} \mathrm{l}^{-1}$ of bacterial inoculum. To obtain the inoculum, 201 of water from each site was filtered through $0.6 \mu \mathrm{m}$ poresize Nuclepore filters to remove bacterivores and particulate material. Bacteria were concentrated using either tangential flow filtration with a $0.1 \mu \mathrm{m}$ pore-size filter cartridge (hollow fiber cartridge; H1MP01-43; Amicon, Inc., Beverly, MA, USA) or a Sharples continuous-flow centrifuge at speeds of 20000 to $30000 \mathrm{rpm}$ $(1000$ to $1500 \times \mathrm{g})$ and a flow rate of $80 \mathrm{ml} \mathrm{min}{ }^{-1}$. The concentration factors ranged from 66 - to 200 -fold, with 25 to $38 \%$ bacterial recovery efficiency. In all experiments, the bacterial inoculum was used immediately after concentration.

Bacterial numbers were determined by the acridine orange direct count (AODC) method (Hobbie et. al. 1977) using an Olympus BH-2 epifluorescence microscope. Original concentrations of bacteria in Okefenokee water samples averaged ranged from 1.0 to $1.9 \times 10^{6} \mathrm{ml}^{-1}$, and starting concentrations in the bacterial bioassays averaged about $30 \%$ of this value. Volume measurements were made on an average of 150 cells or 10 fields per filter using an image analysis system (Southern Micro Instruments, Atlanta, GA, USA) calibrated with $1.7 \mu \mathrm{m}$ fluorescent latex beads (Polysciences, Inc.). Average cell size was multiplied by average cell number to calculate total biovolume, and biovolume measurements were converted to cell carbon by assuming a conversion factor of $0.22 \mathrm{~g} \mathrm{C} \mathrm{cm}^{-3}$ (Bratbak \& Dundas 1984). The specific growth rate $(\mu)$ was calculated based on changes in bacterial biovolume.

In Expt 1, the humic substances concentrate and bacterial inoculum were prepared from the SR site and the following treatments were established in duplicate flasks: (1) humic substances at approximately natural concentrations; (2) deionized water; and (3) deionized water with column leachate as a control for possible resin effects. All treatments were incubated in the dark at the in situ temperature at the time of water collection $\left(14^{\circ} \mathrm{C}\right)$ and sampled periodically over the next $7 \mathrm{~d}$ for determination of bacterial biovolume.

In Expt 2, humic substance concentrates and bacterial inocula were prepared from the CP, CS, and SS sites. Duplicate flasks of humic substances at approximately natural concentration were inoculated with a bacterial concentrate either from the same site or from one of the other 2 sites in all 9 possible combinations; likewise, duplicate flasks of column leachate controls were also set up and inoculated with bacteria from each site. Two additional treatments were established. one with a lower concentration of SS humic substances $(0.5 \times)$, and one with a lower concentration of column leachate $(0.5 \times)$; these 2 treatments were inoculated with bacteria from the SS site. Flasks were incubated in the dark at the in situ temperature at the time of water collection $\left(16^{\circ} \mathrm{C}\right)$ and sampled periodically over the next $6 \mathrm{~d}$ for determination of bacterial biovolume.

In Expt 3, the humic substances concentrate and bacterial inoculum were prepared from the MP site. Humic substances were reconstituted at $1 x$ and $0.5 \times$ natural concentration and incubations were carried out in BOD (biologial oxygen demand) bottles in the dark at room temperature $\left(21^{\circ} \mathrm{C}\right.$; in situ temperature at the time of water collection was $28^{\circ} \mathrm{C}$ ). Periodically over the next $5 d, 2$ bottles were sacrificed from all treatments for determination of bacterial biovolume. In the $1 \times$ treatments only, 5 replicate bottles were also sacrificed for measuring oxygen concentration using the precision Winkler method with a Mettler DL21 automatic titrator (Pomeroy et al. 1994).

\section{RESULTS}

Bacterial volumes in Expt 1 increased from an initial value of $0.04 \times 10^{6} \mathrm{\mu m}^{3} \mathrm{ml}^{-1}$ to a maximum biovolume of $1.0 \times 10^{6} \mu^{3} \mathrm{ml}^{-1}$ by Day 5 (Fig. 1). The column leachate control supported accumulations of biomass no higher than the deionized controls $\left(0.20 \times 10^{6} \mu^{3}\right.$ $\mathrm{ml}^{-1}$ ), indicating that contamination due to the humic substances isolation procedure was minimal.

Bacterial biovolume increased to approximately $0.5 \times$ $10^{6} \mu^{3} \mathrm{ml}^{-1}$ in 8 of 9 treatments in Expt 2, regardless of the source of the humic substances or bacterial inoculum (Fig. 2). The exception was humic substances from the CP site inoculated with bacteria from this same site; in this treatment, the bacteria initially grew at nearly twice the rate measured in the other treatments (Fig. 2). 


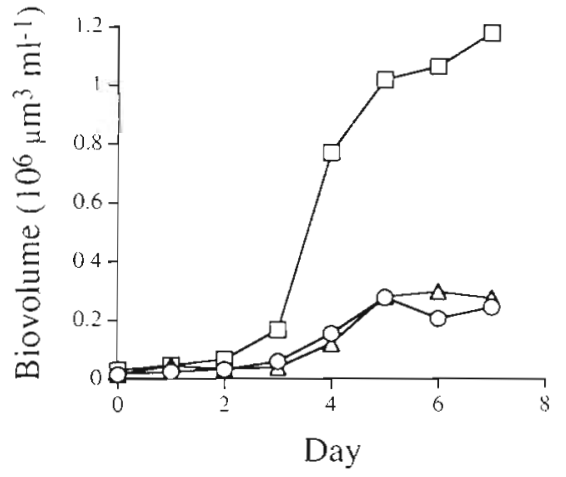

Fig. 1 Changes in bacterial biovolume over a $7 \mathrm{~d}$ incubation (Expt 1) during growth on humic substances ( $\square$ ), deionized water alone $(O)$, and deionized water with column leachate $(\Delta)(n=2 \pm 1 \mathrm{SE})$. Humic substances and bacteria were both from the SR site

As in Expt 1, there was little or no growth of bacteria in the column leachate treatments at $1 \times$ or at $0.5 \times$ concentrations (Fig. 2). When SS bacteria were provided with half the natural concentration of SS humic substances $(0.5 \times$ treatment $)$, the final bacterial biovolume was approximately half that at the $1 \times$ concentration $\left(0.23 \times 10^{6}\right.$ $\mu \mathrm{m}^{3} \mathrm{ml}^{-1}$ ) (Fig. 2)

Bacterial biovolume in Expt 3 reached a maximum value of $0.35 \times 10^{6} \mathrm{~mm}^{3} \mathrm{ml}^{-1}$ in the $1 \times$ treatment after $1.5 \mathrm{~d}$ of incubation, and approximately half that value $\left(0.18 \times 10^{6} \mu \mathrm{m}^{3} \mathrm{ml}^{-1}\right)$ in the $0.5 \times$ treatment (Fig. 3). The total oxygen consumption over $1.5 \mathrm{~d}$ (corrected for small oxygen decreases in the controls) was $17 \mu \mathrm{MO}_{2}$. Growth efficiency was calculated to be $22 \%$, based on bacterial respiration (17 $\mu \mathrm{M} \mathrm{O}_{2}$ ) and bacterial biomass yield (58 $\mu \mathrm{g}$ $\mathrm{Cl}^{-1}$ or $4.8 \mu \mathrm{MC}$ ) in the $1 \times$ humic substances treatment, and assuming a bacterial respiratory quotient of $1\left(\mathrm{CO}_{2}: \mathrm{O}_{2}\right)$. Changes in DOC concentration could not be reliably measured (they were small relative to the pool size) and therefore could not be used as an alternative approach to calculating growth efficiency. Previously, Tranvik \& Höfle (1987) and Tranvik (1988) estimated bacterial growth efficiency on lake water with high concentrations of humic substances to be $26 \%$ based on measurements of bacterial biomass production and DOC consumption. Thus, our estimates of bacterial growth efficiency on humic substances and the few published values for dissolved organic matter of this type both indicate relatively efficient bacterial utilization of humic substances under conditions of sufficient inorganjc nutrient concentrations.

Cumulative bacterial carbon production, calculated from changes in bacterial biovol- ume between initial and final time points, ranged from 58 to $176 \mu \mathrm{g} \mathrm{C} \mathrm{l}^{-1}$ (Table 2). Inorganic nutrients were more than adequate to support bacterial carbon production (assuming a 5:1 C:N ratio and a 50:1 C:P ratio for bacterial biomass; Fagerbakke et al. 1996), indicating bacterial growth was carbon limited during these experiments. Based on a bacterial growth efficiency of $22 \%$ for all experiments, the rapidly utilizable humic carbon pool (i.e. the fraction used within 5 to 7 d) ranged from 276 to $838 \mu \mathrm{g} \mathrm{C} 1^{-1}$ (Table 2). Humic substances from the SR site had the highest concentration of biologically available carbon (838 $\left.\mu \mathrm{g} \mathrm{C}^{-1}\right)$ and humic substances from the MP site had the lowest (276 $\mu \mathrm{g} \mathrm{C} \mathrm{l}^{-1}$ ). Normalized to humic substance concentrations, bacterial carbon demand ranged from 7.4 to

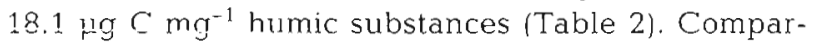
isons between the 3 sites sampled at the same time (CP, CS, and SS in Expt 2) revealed no significant differences in biological availability of humic substances (ANOVA; $p>0.99$ ). Approximately 1 to $2 \%$ of the humic substances was utilized by bacteria for all sites during these short-term experiments.

\section{DISCUSSION}

Because vegetation in the Okefenokee Swamp is a mosaic of many distinctive habitats, we had hypothesized that chemical composition and biological availability of humic substances might vary among sites, as
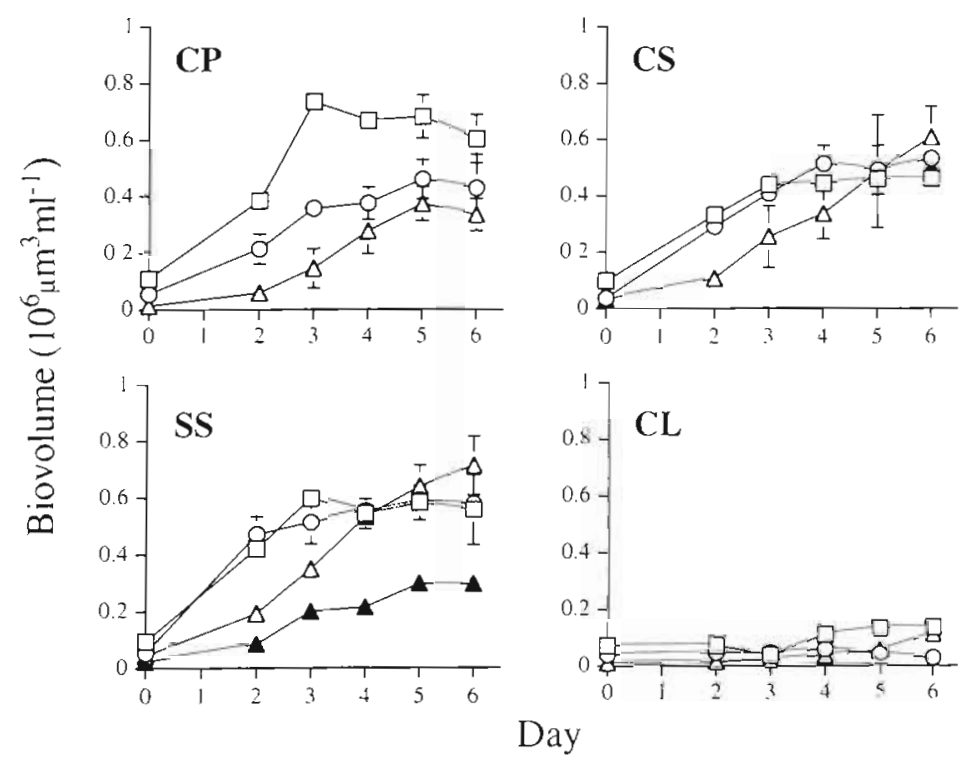

Fig. 2. Changes in bacterial biovolume over a $6 \mathrm{~d}$ incubation (Expt 2) during growth on humic substances from 3 sites (CP. CS, and SS) and in column leachate controls (CL) ( $n=2 \pm 1 \mathrm{SE}$ ). Bacterial inoculum is from the CP ( $\square)$, CS $(O)$, or SS $(\Delta)$ sites, or from the SS site in $0.5 \times S S$ humic substances ( 
Table 2. Utılization of humıc substances during bacterial growth studies ( $n=2 \pm 1$ SE)

\begin{tabular}{|c|c|c|c|c|c|c|}
\hline Expt & $\begin{array}{l}\text { Humic } \\
\text { substances } \\
\text { source }\end{array}$ & $\begin{array}{l}\text { Bacterial } \\
\text { inoculum } \\
\text { source }\end{array}$ & $\begin{array}{c}\text { Initial } \\
\text { humic } \\
\text { substances } \\
\text { (mg C l') }\end{array}$ & $\begin{array}{c}\text { Bacterial } \\
\text { yield } \\
\left(\mu g \mathrm{Cl}^{-1}\right)\end{array}$ & $\begin{array}{l}\text { Bacterial } \\
\text { carbon } \\
\text { demand } \\
\left(\mu g \mathrm{Cl}^{-1}\right)\end{array}$ & $\begin{array}{c}\text { Bacterial } \\
\text { carbon demand } \\
\text { ( } \mu \mathrm{g} \mathrm{C} \mathrm{mg}^{-1} \\
\text { humic substances) }\end{array}$ \\
\hline 1 & SR & SR & 46.4 & $176 \pm 4$ & 838 & 18.1 \\
\hline 2 & $C P$ & $C P$ & 44.3 & $145 \pm 8$ & 690 & 15.6 \\
\hline 2 & $\mathrm{CP}$ & $\mathrm{CS}$ & 44.3 & $89 \pm 16$ & 424 & 9.6 \\
\hline 2 & $C P$ & SS & 45.1 & $70 \pm 28$ & 333 & 7.4 \\
\hline 2 & $\mathrm{CS}$ & $C P$ & 41.5 & $82 \pm 6$ & 390 & 9.4 \\
\hline 2 & $\mathrm{CS}$ & $\mathrm{CS}$ & 41.9 & $100 \pm 15$ & 476 & 11.4 \\
\hline 2 & $\mathrm{CS}$ & SS & 42.7 & $104 \pm 25$ & 495 & 11.6 \\
\hline 2 & SS & $C P$ & 51.3 & $118 \pm 6$ & 562 & 11.0 \\
\hline 2 & SS & $\mathrm{CS}$ & 51.5 & $118 \pm 1$ & 562 & 10.9 \\
\hline 2 & SS & SS & 51.4 & $122 \pm 17$ & 581 & 11.3 \\
\hline 2 & $\operatorname{SS}(0.5 x)$ & SS & 23.4 & $47 \pm 14$ & 224 & 9.6 \\
\hline 3 & MP & $\mathrm{MP}$ & 35.2 & $58 \pm 1$ & 276 & 7.8 \\
\hline 3 & $\operatorname{MP}(0.5 x)$ & $\mathrm{MP}$ & 19.0 & $28 \pm 3$ & 133 & 7.0 \\
\hline
\end{tabular}

might the degradative abilities of the resident bacteria. This generally was found not to be the case, with the exception of more rapid growth observed on CP humic substances when inoculated with resident bacteria. Chemical characterization indicated that CP humic substances had lignin phenol concentrations more than twice that of the other sites (Table 1), suggesting differences in DOC composition. Murray \& Hodson (1986) previously found DOC from the CP site to be inhibitory to bacterial growth, presumably because of secondary compounds released from the vegetation that dominates this habitat (primarily Nuphar advena). Our results suggest that resident bacterial communities may be better adapted to either the unique chemical characteristics of humic substances at this site or to the presence of inhibitory substances.

Humic substances in the Okefenokee Swamp ecosystem have the potential to play an important trophodynamic role because of their characteristically high concentrations. We calculated the specific growth rates $(\mu)$ for bacteria in the bioassays, which are using humic substances as their sole carbon source, based on increases in biovolume between the end of the initial lag period (if any) and the timepoint at which biomass accumulation began to slow down (usually a 3 to $5 \mathrm{~d}$ period). Specific growth rates averaged $0.030 \pm 0.009 \mathrm{~h}^{-1}$ in Expt 1 ( $23 \mathrm{~h}$ doubling time), $0.026 \pm 0.007 \mathrm{~h}^{-1}$ in Expt 2 ( $27 \mathrm{~h}$ doubling time), and $0.044 \pm 0.003 \mathrm{~h}^{-1}$ in Expt 3 $(1 \times$ treatment; $16 \mathrm{~h}$ doubling time). Because these experiments were carried out using a batch culture approach with no new inputs of humic substances occurring during the incubations, the calculated $\mu$ is expected to underestimate bacterial growth rates on humic substances in the natural system. Nonetheless, estimates of specific growth rates on dissolved humic substances are similar to estimates of specific growth rates in situ at the Mizell Prairie site from May 1990 through February $1991\left(0.024 \pm 0.009 \mathrm{~h}^{-1}\right.$; Moran \& Hodson 1992) and at 5 different sites from August 1982 through August 1983 (0.006 to $0.21 \mathrm{~h}^{-1}$; Murray \& Hodson 1985). These similarities in specific growth rates indicate that a portion of the humic substances pool is of similar substrate quality, as the bulk DOC (humic plus non-humic components). Moran \& Hodson (1990) previously found roughly equal contributions of humic and non-humic components of Okefenokee Swamp DOC to bacterial secondary production during growth in batch cultures.

The dissolved humic substances in the Okefenokee Swamp are in large part formed in situ, and ${ }^{14} \mathrm{C}$ aging indicates that they are derived from plant material of recent origin $(<30 \mathrm{yr}$ ) rather than from solubilization of

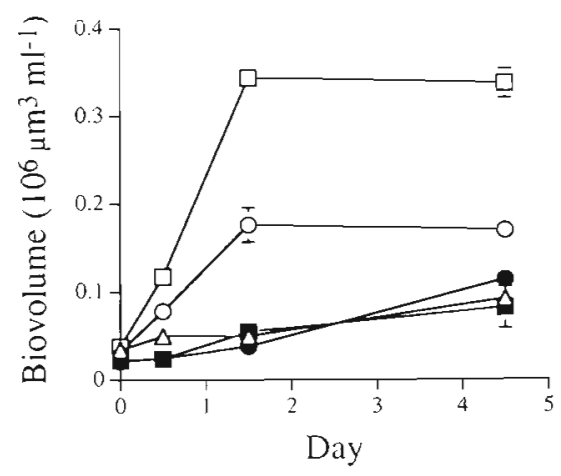

Fig. 3. Changes in bacterial biovolume over a 4.5 d incubation (Expt 3) during growth on humic substances at $1 \times$ natural concentration $(\square)$, humic substances at $0.5 \times$ natural concentration $(O)$, deionized water alone $(\Delta)$, deionized water with column leachate at $1 \times$ concentration $(\boldsymbol{\square})$, and deionized water with column leachate at $0.5 \times$ concentration $(n=2 \pm 1 \mathrm{SE})$. Humic substances and bacteria were both from the MP site 
older peat stores (Thurman \& Malcolm 1989). Nonetheless, the fraction of the humic substances pool susceptible to bacterial degradation within the time frame of these studies was small, accounting for only 1 to $2 \%$ of the total. If only a relatively small fraction of the humic substances pool is eventually utilized by bacteria, the fate of the remainder is of significant interest. One possibility is the active conversion of the biologically refractory component of humic substances into more labile compounds. Transfer into the labile pool might be mediated by processes such as exposure to UV light (Kieber et al. 1989, 1990) or oxidation of humic substances by manganese-oxidizing bacteria (Sunda \& Kieber 1994).

Acknowledgements. We thank E. Sheppard for technical assistance, and M. Skippy Reeves and Sara B. Alcher of the U.S. Fish and Wildlife Service at the Okefenokee National Wildlife Refuge for cooperation during field work. L. Tranvik made valuable comments on an earlier version of this manuscript. This research was funded by National Science Foundation grant DEB 9222479 .

\section{LITERATURE CITED}

Aiken GR (1985) Isolation and concentration techniques for aquatic humic substances. In: Aiken GR, McKnight DM, Wershaw RL, MacCarthy P (eds) Humic substances in soil, sediment and water. Wiley, Chichester, p 363-385

Aiken GR (1988) A critical evaluation of the use of macroporous resin for the isolation of aquatic humic substances. In: Frimmel FH, Christman RF (eds) Humic substances and their role in the environment. Wiley, Chichester, p 15-28

Bratbak G, Dundas I (1984) Bacterial dry matter content and biomass estimations. Appl Environ Microbiol 48:755-757

Fagerbakke KM, Heldal M, Norland S (1996) Content of carbon, nitrogen, oxygen, sulfur and phosphorus in native aquatic and cultured bacteria. Aquat Microb Ecol 10: $15-27$

Hedges JI, Ertel JR (1982) Characterization of lignin by gas capllary chromatography of cupric oxide oxidation products. Anal Chem 54:174-178

Hessen DO (1985) The relation between bacterial carbon and dissolved humic compounds in oligotrophic lakes. FEMS Microbiol Ecol 31:215-223

Hobbie JE, Daley RJ, Jasper S (1977) Use of Nucleopore filters for counting bacteria by epifluorescence microscopy. Appl Environ Microbiol 33:1225-1228

Kieber DJ, McDaniel J, Mopper K (1989) Photochemical source of biological substrates in sea water-implications for carbon cycling. Nature 341:637-639

Kieber RJ, Zhou X, Mopper K (1990) Formation of carbonyl compounds from UV-induced photodegradation of humic

Responsible Subject Editor: K. Šmek, Ceské Budèjovice. Czech Republic substances in natural waters: fate of riverine carbon in the sea. Limnol Oceanogr 35:1503-1515

Leenheer JA, McKnight DM, Thurman EM, MacCarthy $P$ (1989) Structural components and proposed structural models of fulvic acid from the Suwannee River. In: Averett RC, Leenheer JA, McKnight DM, Thorn KA (eds) Humic substances in the Suwannee River, Georgia: interactions, properties and proposed structures. U.S. Geological Survey Open-File Report 87-557, p 331-359

Moran MA. Hodson RE (1990) Bacterial production on humic and nonhumic components of dissolved organic carbon Limnol Oceanogr 35:1744-1.756

Moran MA, Hodson RE (1992) Contribution of three subsystems of a freshwater marsh to total bacterial secondary productivity. Microb Ecol 24:161-170

Moran MA, Hodson RE (1994a) Support of bacterioplankton production by dissolved humic substances from three marine environments. Mar Ecol Prog Ser 76:1.75-184

Moran MA, Hodson RE (1994b) Dissolved humic substances of vascular plant origin in a coastai marine environnent Limnol Oceanogr 39:762-771

Murray RE, Hodson RE (1985) Annual cycle of bacterial secondary production in five aquatic habitats of the Okefenokee Swamp ecosystem. Appl Environ Microbiol 49:650-655

Murray RE, Hodson RE (1986) Influence of macrophyte decomposition on growth rate and community structure of Okefenokee Swamp bacterioplankton. Appl Environ Microbiol 51:293-301

Pomeroy LR, Sheldon JE, Sheldon WR (1994) Changes in bacterial numbers and leucine assimilation during estimations of microbial respiratory rates in seawater by the precision Winkler method. Appl Environ Microbiol 60:328-332

Sunda WG, Kieber DJ (1994) Oxidation of humic substances by manganese oxides yields low-molecular-weight organic substrates. Nature 367:62-64

Thurman EM (1985) Organic geochemistry of natural waters. Martinus Nijhoff/Dr W. Junk Publishers, Dordrecht

Thurman EM, Malcolm RL (1989) Nitrogen and amino acids in fulvic and humic acids from the Suwannee River In: Averett RC, Leenheer JA, McKnight DM, Thorn KA (eds) Humic substances in the Suwannee River, Georgia: interactions, properties and proposed structures. U.S. Geological Survey Open-File Report 87-557, p 99-118

Tranvik LJ (1988) Availability of dissolved organic carbon for planktonic bacteria in oligotrophic lakes of different humic content. Microb Ecol 16:311-322

Tranvik LJ (1990) Bacterioplankton growth on fractions of dissolved organic carbon of different molecular weights from humic and clear waters. Appl Environ Microbiol 56: $1672-1677$

Tranvik LJ, Höle MG (1987) Bacterial growth in mixed cultures on dissolved organic carbon from humic and clear waters. Appl Environ Microbiol 53:482-488

Tranvik LJ, Sieburth JMcN (1989) Effects of flocculated humic matter on free and attached pelagic microorganisms. Limnol Oceanogr 34:688-699

Manuscript first received: October 15, 1996 Revised version accepted: March 7, 1997 